This is an electronic reprint of the original article. This reprint may differ from the original in pagination and typographic detail.

Author(s): Häkkinen, Teemu

Title: $\quad$ Challenging the Royal Prerogative : the Decision on War against Iraq in Parliamentary Debates in 2002-3

Year: $\quad 2016$

Version:

Please cite the original version:

Häkkinen, T. (2016). Challenging the Royal Prerogative : the Decision on War against Iraq in Parliamentary Debates in 2002-3. Parliamentary History, 35(1), 54-66. https://doi.org/10.1111/1750-0206.12184

All material supplied via JYX is protected by copyright and other intellectual property rights, and duplication or sale of all or part of any of the repository collections is not permitted, except that material may be duplicated by you for your research use or educational purposes in electronic or print form. You must obtain permission for any other use. Electronic or print copies may not be offered, whether for sale or otherwise to anyone who is not an authorised user. 


\title{
Challenging the Royal Prerogative: The Decision on War against Iraq in Parliamentary
}

\section{Debates in 2002-3}

\author{
Teemu Häkkinen \\ University of Jyvaskyla
}

\begin{abstract}
The use of military force is an excellent example of how the decision-making process has traditionally been carried out by the executive. However, the role of parliamentary decision-making in this area has gradually emerged as a topic for constitutional discussion in the house of commons. The decision to go to war in Iraq in 2002-3 is considered to have been a culmination point for the role of parliament in decision making about the deployment of troops abroad and the use of military force. In addition to the need for international authorisation, the decision to go to war was preceded by a clear parliamentary preference for a domestic mandate for participation, delivered by means of a vote in the house of commons. This article argues that as a result of this emphasis on domestic political authorisation, the royal prerogative (the residual powers of the sovereign that are exercised by the ministers of the government) has been subjected to broader discussion in plenary sittings since the Second World War. Furthermore, this constitutional debate continued after the invasion of Iraq had begun and the operations against Iraq’s conventional forces had turned into insurgency warfare.
\end{abstract}


Key words: British parliament, foreign policy, defence policy, Iraq War, royal prerogative, constitutional debate

The British involvement in the war against Iraq in 2003 shows how the house of commons was able to exercise foreign policy. The use of the royal prerogative in British parliamentary democracy has led to the executive branch exercising the central role in decision making. Parliamentary democracy in Britain has been achieved through the convention that the ministers are accountable to parliament. ${ }^{1}$ The decision to go to war with Iraq in order to disarm the country of its alleged weapons of mass destruction in 2003 was significant from a parliamentary perspective since the approval to use force was issued in the house of commons.

The run-up to the war offers a suitable subject for examining the question of how the house of commons viewed its constitutional role in the exercise of foreign and defence policies in the decision to go to war with Iraq, first by deploying troops to the Middle East and then by authorizing the troops to use force. It is important to place this parliamentary discussion in its historical context in order to understand the deliberations in 2002 and 2003 as the culmination of a longer parliamentary discussion about the power of parliament. The run-up to the Iraq War covers an extended period of time, in which parliament was able to consider and review the government's policy in various situations. Above all, parliament had a chance to approve government policy through a vote on a substantive motion in the Commons. Furthermore, because parliament was the primary forum for constitutional change, this discussion also provided an opportunity and a logical context for airing ideas about power rights at a time in which they were being used or about to be used. ${ }^{2}$ In this article the answer to the question of parliament's view of its constitutional role is 
sought through an analysis of parliamentary speaking on the Iraq policy between September 2002 and March 2003.

\section{The Royal Prerogative and Parliament}

Historically, the state of the constitution and its relation to the royal prerogative has not been stagnant; as is well known, the major features of the relationship between the crown and parliament were established in the Bill of Rights in 1689, which restricted the use of prerogatives. ${ }^{3}$ However, during the 19th century the role of parliament in relation to the royal prerogatives was no longer generally questioned. ${ }^{4}$ The royal prerogative rights were a part of the British constitution, and parliament was considered to have a part in the use of these rights since the monarch was but one element in the legislature. This was emphasized by the fact that the exercise of these rights was transferred from the monarch to the executive, which was then accountable to parliament. ${ }^{5}$ Since the Second World War, there has been a fairly stable relationship between parliament and the executive in decisions to use the armed forces. The executive has used the royal prerogative to make decisions and usually has informed parliament afterwards about its actions.

In the unwritten constitution, the use of force abroad is one specific area of foreign policy, and it is also related to the exercise of defence policy; both are based on the exercise of royal prerogative rights. The constitutional role of the Commons depends on a number of principles. First of all, the executive holds the royal prerogative right to deploy troops abroad. This power is described as 'a deployment power' in the official language, and going to war requires the deployment of troops. The right to use this power is considered to be personally vested in the prime minister. ${ }^{6}$ The government is accountable to parliament for the exercise of its powers. Parliament has a right to decide on the financial provision for the military deployment, but the government, through its majority, is able to influence the exercise of this right. A further pertinent factor is the 
fact that emergency situations are funded from a special emergency fund, already approved as part of the state's budget. ${ }^{7}$ The operational aspect and concomitant details are also exercised under the royal prerogative right. ${ }^{8}$ To conclude, the major role of the Commons seems to consist in organising public debates in plenary sessions and thereby providing support and upholding government by discussion. ${ }^{9}$ Constitutional changes, on the other hand, are carried out through the same kind of legislative process in parliament as any other legislative issue, even during a time of crisis.

During the previous armed conflicts in which Britain had participated, the role of parliament was not the subject of broad discussion. In 1957, after the experiences of the Suez Crisis, Arthur Woodburn (Lab.) had asked Prime Minister Harold Macmillan if the government was planning to introduce a law requiring parliamentary approval before Britain could embark on war or an armed conflict, but Macmillan rejected the idea. ${ }^{10}$ In 1982, during the Falklands War, the opposition tried, in a limited fashion, to gain more power especially in deciding about the direction of diplomatic negotiations. However, Prime Minister Margaret Thatcher strongly emphasized that parliament’s role was to give its judgment on the government's actions afterwards. ${ }^{11}$ In $1990-1991$, in relation to the Gulf Crisis and to the war that broke out in January 1991, the role of parliament was touched on again, this time with regard to having a vote before the use of force. As was the case with the Kosovo War nine years later, the key issue was the role of international legal authorisation before the use of military force. ${ }^{12}$

Calls in parliament for stronger parliamentary control of the royal prerogative emerged during the 1980s. These views were met with suspicion by the government. In 1981 the view of the British constitution as the 'envy of the world' was raised in the Commons to remind the House of how the British political system had traditionally been seen. ${ }^{13}$ A year before, the political system had come under attack. Tony Benn, a Labour MP and a former member of the cabinet, aired his concern over the current political system first in 1980 and again in 1982 as a result of the prosecution of the Falklands War, of which he was one of the major critics, as Jonas Harvard notes in his article on the 
role of world opinion. ${ }^{14}$ Benn also introduced two bills in parliament, the first in $1985^{15}$ and the second, The Crown Prerogatives (House of Commons Control) Bill, in $1988 .{ }^{16}$ Neither of Benn’s initiatives advanced further, but the discussion on the issue they addressed, the state of the constitution, broadened and remained on the agenda. It was significant that it was a former frontbench member who began to critically address the foundation of the political system, and Benn was the most prominent MP to bring up the question the royal prerogative rights in plenary debates. In 1991 Benn called the prerogative rights 'an old feudal anachronism, ${ }^{\text {, }}$, a message that was repeated by John Garrett (Lab.) in 1993 when the house of commons debated his initiative on the royal prerogative. ${ }^{18}$ Both comments expressed the view that the exercise of royal prerogative rights in their current form was outdated and ill-suited to the needs of a modern parliamentary democracy.

The Labour Party had revised its approach towards the reform of the constitution since the end of 1980s, and in 1993 the party stressed the need to place the declaration of war under parliamentary control. ${ }^{19}$ This was not surprising since the 1980 s had started to witness broad criticism of the state and its authoritarian elements, one manifestation of which was the formation of the non-party group Charter 88 in 1988 to give publicity to views it considered important. Among many other issues, it called for a written constitution, a bill of rights and a more equitable division of power between central and local government. The group was led by Richard Holme, the former president of the Liberal Party. ${ }^{20}$ In 1994 Jack Straw, a Labour MP, the shadow secretary of state for the environment and the future foreign secretary (2001-6), called for the abolition of royal prerogative rights as a part of Charter 88's programme for a written constitution. However, as Straw also noted, parliament's current legal existence was linked to the royal prerogative and was related to the whole structure of relations between the monarch and parliament. ${ }^{21}$ This underlined the importance of the royal prerogative in the British political system and the fact that the exercise of foreign policy was fundamentally the preserve of the sovereign. 
After its election victory in 1997, the Labour Party embarked on broad constitutional reforms. However, measures to broaden parliament's control over royal prerogative rights were not included in the implementation of the programme; in fact, the party leadership was cautious since a reform of these rights would limit the powers of the government. ${ }^{22}$ Nevertheless, the reformist discussion also emerged in relation to this topic. In 1999, Britain participated in a NATO-led combat operation against Serb targets, which was intended to bring an end to the escalating crisis in Kosovo. After the war, the select committee on foreign affairs found that the operation had lacked a legal mandate but was morally justified. What was different compared to previous reports of the foreign affairs committee since its establishment in 1979 was that the subsequent report raised the issue of the role of parliament. The committee recommended that in future combat operations parliament should be given a say as soon as possible through a substantive motion, an element that was mostly missing from plenary sittings in $1999 .^{23}$

In the Gulf War, international authorisation existed in the form of United Nations security council resolution 678, issued in November 1990. This resolution required Iraq to withdraw its forces from Kuwait within a certain time frame; if it failed to implement the conditions of the resolution during the time frame, the member states of the security council were authorised to use force. The Labour Party had traditionally considered the legal aspect of the British position on the use of force to be essential, and support from the security council in 1990 was considered important to satisfy this need for legality. In the Commons, this was reasserted in speeches comparing domestic decision making with international-level authorisation and emphasizing the role of the UN security council. In the Commons, the Labour Party, after pressuring the government to seek that authorisation, found the resolution to be satisfactory, at least in general. ${ }^{24}$ The party's antiwar lobby pressed for a parliamentary debate in December 1990, and David Lambie (Lab.) debated with his fellow party member Gerald Kaufman, who was the shadow foreign secretary, about the relationship of the Commons to the United Nations security council as the source of the 
authorisation for the use of force. Kaufman's answer was clear: it was the UN level that would prevail over the Commons. ${ }^{25}$ It was a debate within the Labour Party over the party's stance on foreign policy, but outside the spectrum of the single party, the domestic legislation could also be altered in order to make the role of parliament clearer.

A private member’s bill to introduce legislation to place going-to-war under parliamentary control had already been tabled in early 1999. Tam Dalyell's (Lab.) bill was a result of the brief joint US-British bombing campaign against Iraq, carried out in December 1998 and was intended to prevent further bellicose operations against Iraq without parliamentary approval. Unsurprisingly, Dalyell's bill failed to gain the assent of the queen in order to advance in the legislative process. ${ }^{26}$

The international mandate for military action was the key issue, and it defined the role of parliament even more than the constitutional role of the Commons: if there was an international mandate, the domestic parliamentary evaluation of the moral and legal justifications of the participation would be less significant. In this sense, the wars after the terrorist attacks against the United States on 11 September 2001 also influenced Britain. The participation in the war against the Taliban regime in Afghanistan in October 2001 was implemented after a fairly limited parliamentary process. In fact, the house of commons was summoned to hear about the war in Afghanistan without having the chance to express an opinion through a vote either in an adjournment debate or a debate on a substantive motion. This led Paul Marsden (Lab.) to ask Prime Minister Blair about the introduction of a written constitution that would include the power for parliament to provide the authorisation for a declaration of war, but Blair refused to address the issue at that point. ${ }^{27}$

What was new in the constitutional discussion in 2002-3 was its broadness compared to the discussions related to the armed conflicts that Britain had participated in during the previous decades. Moreover, a cross-party consensus over the need to strengthen parliament's constitutional role in decisions to use military force had begun to emerge, although it did not contain the idea of 
having parliamentary consent before the deployment of troops abroad. In addition to the Labour restrictionists, ${ }^{28}$ the support broadened when the Liberal Democrat front bench started to speak about a stronger parliament during the Kosovo War in $1999 .^{29}$ The Conservative Party also became more positive towards changes in the constitution. ${ }^{30}$

\section{Autumn 2002 and the Role of Parliament}

Between September 2002 and March 2003, the subject of Iraq was constantly present in the Commons. The debate stemmed from the government's critical rhetoric against Iraq. This, linked to a similar critical rhetoric used by the US government after January 2002, emphasized the need to disarm Iraq of its alleged weapons of mass destruction. ${ }^{31}$ The activity in the House suggests that the Commons were eager to evaluate the government's policy and arguments about Iraq and the alleged threat. The House was not ready to hand over the decision making to Prime Minister Blair, and thus the question of legality was discussed extensively. There were four major debates on the topic, and in addition to these Iraq was mentioned almost on a daily basis, for example in business of the house debates and in parliamentary questions. During the political process, several votes were held in parliament. The Commons had a chance to vote three times, on 25 November 2002 on United Nations security council resolution 1441, on 26 February mainly on giving support to the government to continue its efforts in the United Nations to disarm Iraq and on 18 March 2003 on noting the continuing Iraqi failure to comply with the terms imposed by the United Nations security council; as a result of Iraq's behaviour, the government asked the Commons to authorise it to use all necessary means to disarm Iraq. ${ }^{32}$

The political process leading to the war included a discussion about the constitutional role of parliament (meaning the house of commons): this was an exceptional measure, as will be discussed in the following pages. The handling of foreign affairs in the existing political system was the main 
topic, and there were deliberations about whether the system should be changed to resemble that of the United States - a discussion that may have been further activated by a house of commons library research paper Iraq: the debate on policy options, published on 20 September 2002, although this paper was not referred to in the debates on the Iraq policy. The paper outlined, among other matters, the US position on Iraq and discussed the nature of US decision making on the use of force. ${ }^{33}$ In the United States, the War Powers Act of 1973, introduced after the Vietnam War, secured for the congress the right to be consulted before the president would be able to commit troops to hostilities and also gave it the right to authorise the continuation of a military operation after sixty days. ${ }^{34}$

In the first debate on 24 September 2002, carried out as a recall debate, parliament's constitutional position was briefly touched upon, but the issue was not considered important at the time. ${ }^{35}$ However, the right to have a vote by simply forcing the government to promise such a motion became the dominant theme of the parliamentary process, lasting as it did until March 2003. This unprecedented parliamentary behaviour highlighted the changed attitude towards parliament in the context of a controversial policy. The constitutional position surfaced later, after the new parliamentary session had begun.

On 17 October, the Liberal Democrat MP Paul Keetch started the discussion about the constitution by bringing up the idea of introducing a war powers act, resembling that of the United States, into the British system - a move that would, in practice, include the removal of the current royal prerogative right to deploy troops abroad. The main point was the right of parliament to have the vote on a substantive motion prior to any attack against Iraq. ${ }^{36}$ He was answered by Julian Lewis (Con.), a backbencher MP, who was doubtful with regard to the provision of information. What would happen in a scenario in which the prime minister possessed top-secret information but was unable to share it? ${ }^{37}$ His point was that the Commons lacked the possibility to obtain the information needed for good decision-making. 
Nevertheless, the issue of changing the constitutional arrangements had been introduced. On 21 October, a few days after the previous debate, Graham Allen (Lab.), an MP who had been behind a similar questioning of constitutional arrangements since 1991, submitted a written question to Prime Minister Blair. Allen asked whether the prime minister would 'bring forward proposals to make it a requirement for parliament to be consulted on the use of his power under the royal prerogative to take the country into a war'. ${ }^{38}$ In his reply, Blair refused to make any such commitment - he said there was no need for formal changes since the House had already been provided with opportunities for such debates. ${ }^{39}$ This forced Allen to ask for more details with reference to the phrase 'given the opportunity' in Blair's answer in a written question on 7 November, but even then he did not get any definite answer. ${ }^{40}$

At the end of October, Michael Moore (Lib. Dem.) placed a written question pointing out how important it was that parliament should have a role in making decisions relating to the war on terror. ${ }^{41}$ His position did not extend to actual constitutional proposals like the ones made by Allen, who continued to call for a stronger role for parliament and even demanded the publication of advice that the solicitor general had given to the government regarding the legality of action against Iraq. The publication would have been against the convention that the government does not publish the legal advice it receives. ${ }^{42}$ Allen was exceptionally active in questioning the state of the constitution at this point, his actions deriving from his overall political goal of reforming the British political system. ${ }^{43}$ The government in fact published the legal advice in March 2003 after widespread pressure, but this was considered a unique event.

On 4 November 2002, Allen returned to the idea of a parliamentary recall in a written question, asking whether the government was planning any changes to Standing Order no. 13, which regulated the recall of parliament, a key issue in providing the Commons with more power over its agenda in a time of emergency. Prime Minister Blair's answer was negative. ${ }^{44}$ Two weeks later, Allen tried to get Blair to list the royal prerogative rights at his disposal, but the latter turned 
down the request; the proposal that Blair should inform the House every time he used the rights met with a similar fate. This was not the first time that Allen had asked for the listing of the royal prerogative rights as he had made a similar request on 28 January 1991 during the Gulf War. However, his request was turned down on both occasions. ${ }^{45}$ Allen's point addressed an important matter. Discussion of the royal prerogative rights in general was difficult since, as Andrew Blick argues, nobody knows for certain just what those rights are. ${ }^{46}$ The right to commit troops to an armed conflict was known for certain to exist, and it was easier to address that particular right critically.

Norman Baker (Lib. Dem.) continued to push the issue of the royal prerogative at the end of November and asked whether the prime minister would bring forward proposals 'to make it a requirement for Parliament to be consulted prior to each exercise of the power under royal prerogative to take the country to war.' It was practically the same question Graham Allen had asked in October in slightly different words, but it was related to the constitution just as Allen's had been. Both of these MPs were prolific users of parliamentary questions, but the question of whether they collaborated cannot be answered from the parliamentary sources. ${ }^{47}$ In his reply Tony Blair referred only to his answer in October. ${ }^{48}$ Graham Allen, too, continued to press the government. In January he presented two written questions to the president of the council, Robin Cook, and asked if he was changing arrangements for a parliamentary recall or if he would propose enhancements to the current role of parliament regarding 'decisions to deploy British forces in armed conflict overseas'. To the latter question, Cook replied that parliament had been able to debate the issue frequently. ${ }^{49}$ An important point to note is that the questioning of the constitutional situation concentrated on challenging the current deployment powers as well as the right to recall parliament. There was no interest in challenging the operational rights. A similar attitude prevailed when the select committee on the constitution examined the royal prerogative rights. ${ }^{50}$ The committee's 
proposal that parliament should have the right to vote was linked to the deployment power, but it cannot be regarded as an official demand to change the system permanently.

\section{The Prime Minister's View and the last Phase of the Run-up to War}

Although Robin Cook was generally known to be strongly in favour of a prior vote in the house of commons, ${ }^{51}$ he was not ready to depart from the cabinet line on constitutional changes. Even so, a pair of questions in the autumn seems to have had an impact since the state of the constitution was raised in the hearing of the prime minister in the liaison committee. Tony Wright (Lab.) and Sir Nicholas Winterton (Con.), the chairman of the select committee on procedure, raised the question of the role of the house of commons when Blair was being questioned on the Iraq policy. Wright, who was known to be keen on constitutional issues, was the one who opened the discussion by putting the question rather clearly: In the context of previous post-Second-World-War conflicts there had been constant demands for a vote in the Commons - should the conventions now be changed to make the vote official? ${ }^{52}$ Winterton, for his part, asked if the existing constitutional conventions should be changed in order to give the Commons the right to decide on the use of force. Blair considered that the government had the right to go to war, while parliament's task was to hold the government accountable:

I cannot think of a set of circumstances in which a Government can go to war without the support of Parliament, so I do not think it is real. I think you can get into a great constitutional argument about this, but the reality is that Governments are in the end accountable to Parliament, and they are, and they are accountable for any war that they engage in, as they are for anything else. ${ }^{53}$ 
Blair insisted that an American-style war powers act was not needed in Britain. ${ }^{54}$ Hence he was critical of any changes in the royal prerogative rights and emphasized the fact that parliament had already power as the government could not operate without the support of parliament. A post factum parliamentary vote would follow from the right to hold the government accountable. Blair also argued:

So I think that even though it may be strictly true to say that the Royal Prerogative means you do it and in strict theory Parliament is not the authority, in the end Parliament is the authority for any Government, and I cannot - I mean, can you honestly imagine a set of circumstances in which the Government is defeated by Parliament over a conflict and says, 'Well, I'm just ignoring that'? ${ }^{55}$

Blair's position on proposals for constitutional changes followed the line of previous prime ministers in which the executive held precedence over the Commons. The prime minister outlined his views on current constitutional arrangements and other political issues in the liaison committee hearing. The committee provided a forum and the right circumstances not only for commenting on the policy on Iraq but also for reflecting on the decision-making process. ${ }^{56}$ Blair referred to parliament's support as the final source of legitimacy. The Guardian's Simon Hoggart commented sarcastically on Blair's claims. He reminded the readers of a possible situation in which the country's own troops were engaged in action and argued that this affected the way in which it was possible to hold the government accountable. ${ }^{57}$

This questioning of the prime minister and other key cabinet members either in the committees or in the plenary sittings about the role of parliament was connected with the uncertainty about whether parliament would have a vote prior to military action. Foreign Secretary 
Jack Straw had announced in November that the Commons would have its vote, but the timing of the vote remained uncertain until 26 February $2003 .^{58}$

On 18 March 2003, the Commons had a chance to vote about war with a debate on a substantive motion, which saw the Labour Party divided. ${ }^{59}$ The Labour whips strongly pushed reluctant and uncertain Labour MPs to stand behind Blair's policy. It was clear that he was going to resign if he lost the vote. ${ }^{60}$ There was a strong desire to preserve the considerable power enjoyed by the government through its majority in the Commons and a similar desire applied to decisions to deploy troops abroad. Blair's position is unlikely to have been influenced by international opinion. At that moment in January, the reactions of the international community had shown that it would not be easy to obtain wide support for the war. At the time of the hearing in the liaison committee, the weapons inspections were going on and the final struggle in the United Nations security council was still to come. Blair's comments before the liaison committee later became the prime minister's interpretation of the role of parliament with regard to the use of force, but their content was not untraditional, and they reaffirmed a long-standing convention pertaining to the matter. ${ }^{61}$

In February 2003, when the war against Iraq began to look imminent, 143 MPs from all the main parties signed a motion calling for the introduction of a war powers act which would change parliament's role into one more resembling that of the US congress. ${ }^{62}$ The motion did not progress in the Commons, but it showed the government the existence of a broad consensus over the need to have the Commons as the source of authorisation if it planned to use force against the Iraqi regime. Graham Allen submitted a written question in which he asked whether the government would, in the case of the use of force, publish a statement in which the options for the peaceful routes would be considered. ${ }^{63}$ The major advance in the efforts to strengthen parliament occurred when Tony Wright (Lab.), the chairman of the public administration select committee, announced at the beginning of February the committee's intention to conduct an inquiry into the royal prerogative rights. His argument was that the inquiry should have been carried out earlier, and now was finally 
the time to act. ${ }^{64}$ That announcement marked the beginning of a broader parliamentary review of the issue, a review that extended beyond the discussions in the chamber to the committee level. In the end, Foreign Secretary Jack Straw summed up parliament's role in relation to the constitution in the final debate on 18 March 2003:

I have been present when military action by British troops has been debated. However, never before, prior to military action, has the House been asked on a substantive motion for its explicit support for the use of our armed forces. The House sought that, but, more important, it is constitutionally proper in a modern democracy. ${ }^{65}$

It can be argued that the expectations for parliamentary speaking in 2003 were clearly different from those that had previously existed. Tony Benn had reminded the Commons in 1991 that the Gulf War was the first conflict in which parliament was not consulted prior to going to war; in 2003, on the other hand, Straw argued that the role of parliament had strengthened significantly since this was the first time the house of commons was able to decide on the use of force before it was used. That now reflected the existing state of the constitution: the debate and the vote on 18 March 2003 were 'constitutionally proper'.

What is important to notice is the fact that in 2002-3 the idea of a parliamentary vote was broadly endorsed even before embarking on the United Nations route. This meant that, in the end, the issue for MPs was the sovereignty of parliament, not the importance of international organisations. The demands to have a vote emphasized this view. In terms of the constitutional debate, the idea of voting prior to a war was only partly linked to the constitution: there was more emphasis on parliament's need to have the final say over going to war in that particular context and less interest in a long-term constitutional change. All in all, the debate on the use of force against Iraq showed the clash between the traditional constitutional view on the role of parliament and the 
argument for broader parliamentary powers as a necessary development in parliamentary democracy, a process that had been going on for years. ${ }^{66}$

The combat operations against Iraq’s conventional troops ended in April 2003, but the insurgency actions against the coalition troops led to their extended presence in Iraq. In parliament, the experiences and aftermath of the conflict led to several committee-level inquiries. As a result, parliament's role was considered to be in a need of re-evaluation. The committee stage began to consider the role of parliament in the decision-making about the war in Iraq as a precedent. The select committee on public administration in the house of commons even called for a law to place the exercise of royal prerogative rights under parliamentary control in 2004, and the select committee on the constitution also recommended restrictions on the use of the royal prerogative. ${ }^{67}$ Furthermore, in 2004-7 there were three private members bills aiming to strengthen the parliamentary control of the armed forces which had with all-party endorsement and were supported by Prime Minister Gordon Brown. ${ }^{68}$

After 2007, the process of actually reforming the exercise of foreign policy has slowed down and has not led to any formal changes. However, one of the consequences of the Iraq War was a broad interest in bringing parliament's power rights closer to the requirements of parliamentary democracy rather than pursuing the further centralisation of power, which had been a feature of Prime Minister Tony Blair's premiership, for example, during the run-up to the war in Iraq. ${ }^{69}$

Nevertheless, the house of commons debate and vote on potential British participation in the Syrian Civil War in August 2013 confirmed that the Iraq War had left a lasting impression. It also created an important precedent in the discussion on whether parliament should play a role before embarking to war. In 2013, the house of commons rejected the government's foreign policy motion in a rather historic manner. ${ }^{70}$

\section{Conclusion}


Certain conclusions can be drawn from the parliamentary discussion of parliament's constitutional role in the exercise of foreign and defence policies. In the relationship between the international and national levels, the lack of an international mandate for the use of military force made it more important to have domestic authorisation. However, the desire of parliament to have a stronger role was not determined by factors at the international level in 2002-3. The broader parliamentary participation was facilitated by the extended period leading up to the use of force. This was partly influenced by the changed situation and the challenges brought by it and also by the existence of an international object of comparison: Britain's main ally in a potential war against Iraq, the United States, where the congress approved the war in the autumn of 2002, and this placed more pressure on Britain.

The case also confirms the conclusion that the active work of key actors such as committee chairmen and front benchers are important in raising issues for discussion. Furthermore, the analysis has given us reason to argue that there may not necessarily be a constitutional debate even at a time when the rights in question are actually being used. This point is further underlined by the practice of holding extensive examinations in the form of inquiries on contested issues. If the constitutional debate can be linked to an event that creates discussion, in this instance the decision on going to war, the examination can extend beyond this particular event and in doing so contribute to the constitutional debate generally. A good example is the inquiry on the royal prerogative as a whole which was initiated in 2003 in the middle of the discussions on the role of parliament with regard to war. However, any discussion on a delicate issue like the constitution depends on the context that induces the parliamentary parties to examine it. The appearance of such a discussion is not self-evident even during a time in which major constitutional changes and debates have just taken place in other areas of the political system. Going to war remains a matter of delicate deliberation, with or without a broader role for parliament. 
${ }^{1}$ HL Deb 1 Dec. 1994 vol. 559 c49WA, Cranborne.

${ }^{2}$ Philip Norton, 'Introduction: A Century of Change', Parliamentary History, xxx, 1 (2011), 2.

${ }^{3}$ D.L. Keir, The Constitutional History of Modern Britain 1485-1951 (6th edn, 1961), 230-43.

${ }^{4}$ There is one important exception. The reform of the commanding structure of the army at the end of the 19th century reduced the royal prerogative powers of the monarch. John Stuart Omond, Parliament and the Army 1642-1904 (Cambridge, 1933, 2009), 140-55.

${ }^{5}$ Jeffrey Goldsworthy, The Sovereignty of Parliament: History and Philosophy (Oxford, 1999), 9.

${ }^{6}$ See for example Peter Richards, Parliament and Foreign Affairs (1967), 36; House of lords select committee on the constitution. Session 2005-06. 15th report. Waging war: Parliament's role and responsibility. Volume I: Report. Ordered to be printed 19 July and published 27 July 2006. HL Paper 236-I (London: The Stationery Office), http://www.publications.parliament.uk/pa/ld200506/ldselect/ldconst/236/236i.pdf, 27 Sept. 2013, 8. ${ }^{7}$ In the UK, the run-up to and participation in the Iraq War was financed from the treasury special reserve, which was a part of the ministry of defence’s annual budget, meant for military operations overseas. The costs during the run-up in 2002-3 did not exceed the budget. HL Deb 14 Oct. 2003 vol. 653 c107WA.

${ }^{8}$ Officially, the operational details are in the hands of the government but often delegated to the military. This view was also emphasized in the committee report. House of lords select committee on the constitution. Session 2005-06. 15th report, 8-9.

${ }^{9}$ See Hans Born \& Marlene Urscheler, 'Parliamentary Accountability of Multinational Peace Support Operations: A Comparative Perspective' in The 'Double Democratic Deficit'. 
Parliamentary Accountability and the Use of Force Under International Auspices, ed. Hans Born and Heiner Hänggi (Aldershot and Burlington, 2004), 70-1.

${ }^{10}$ HC Deb 22 Jan. 1957 vol. 563 cc5-6W.

${ }^{11}$ HC Deb 11 May 1982 vol. 23 cc597-8.

${ }^{12}$ For example Michael Howard (Folkestone and Hythe) and Menzies Campbell (Fife North East) commented the legal aspects of the intervention. HC Deb 25 Mar. 1999 vol. 328 c543, c547.

${ }^{13}$ HC Deb 10 Apr. 1981 vol. 2 c1213, John Stokes (Halesowen and Stourbridge, Con.).

14 Tony Benn, 'The Case for Constitutional Premiership’, Parliamentary Affairs, xxxiii, 1, (1980),

7-13, 19-22; Tony Benn, Parliament, People and Power (1982), 44-8, 51-3.

${ }^{15}$ HC Deb 24 May 1985 vol. 79 c1253.

${ }^{16}$ HC Deb 16 Mar. 1988 vol. 129 c1109.

${ }^{17}$ HC Deb 15 Jan. 1991 vol. 183 c777.

${ }^{18}$ HC Deb 21 Apr. 1993 vol. 223 c487.

19 Jack Straw, 'Abolish The Royal Prerogative' in Power and the Throne. The Monarchy Debate, ed. Anthony Barnett (1994), 127.

${ }^{20}$ Patrick Wintour, ‘Group seeks constitutional reform’, The Guardian, 30 Nov. 1988, 7.

${ }^{21}$ Straw, 'Abolish', 125-9; Erskine May’s Treatise on the law, privileges, proceedings and usage of Parliament, ed. C.J. Boulton (21st edn, 1989), 8.

${ }^{22}$ Peter Dorey, The Labour Party and Constitutional Reform: A History of Constitutional Conservatism (Basingstoke and New York, 2008), 93.

${ }^{23}$ House of commons foreign affairs committee. Session 1999-2000. Fourth Report. Kosovo. Report and proceedings of the committee. Ordered by the house of commons to be printed 23 May 2000. HC 28-I (The Stationery Office, 2000), 
http://www.publications.parliament.uk/pa/cm199900/cmselect/cmfaff/28/2802.htm, 10 Apr. 2013, paragraphs 2, 137.

${ }^{24}$ Mark Phythian, The Labour Party, War and International Relations, 1945-2006 (London and New York, 2007), 94-104.

${ }^{25}$ HC Deb 11 Dec. 1990 vol. 182 c836-7.

${ }^{26}$ HC Deb 26 Jan. 1999 vol. 324 cc146-7; HC Deb 16 Apr. 1999 vol. 329 c541.

${ }^{27}$ HC Deb 8 Oct. 2001 vol. 372 c823; Vikram Dodd, 'Model of meritocracy that Britain could learn from America’, The Guardian, 3 Oct. 2001, 3.

${ }^{28}$ Phythian, The Labour Party, 129.

${ }^{29}$ HC Deb 15 June 2000 vol. 351 c1156. The Liberal Democrats had advocated changes to the British political system ever since the creation of the party, but the constitutional problems related to armed conflicts were not addressed.

${ }^{30}$ Matthew Flinders, 'Shifting the balance. Parliament, the Executive and the British Constitution', Political Studies, l (2002), 27-8.

${ }^{31}$ George W. Bush, 'State of the Union Address (excerpt), 29 January 2001' in The Iraq Papers, ed. John Ehrenberg, J. Patrice McSherry, José Ramón Sánchez and Caroleen Marji Sayej (New York, 2010), 59-61.

32 HC Deb 26 Feb. 2003 vol. 400 c265; HC Deb 18 Mar. 2003 vol. 401 c760.

${ }^{33}$ International Affairs and Defence Section, Iraq: the debate on policy options, 20 Sept. 2002. House of commons library research paper 02/53, http://www.parliament.uk/briefing-papers/RP0253.pdf, 27 Sept. 2013, 69.

${ }^{34}$ The War Powers Act of 1973, The United States Public Law 93-148, 93rd Congress, H. J. Res. 542, 7 Nov. 1973.

${ }^{35}$ See, for example, HC Deb 24 Sept. 2002 vol. 390 c97, Garnier. 
${ }^{36}$ The debate was a themed debate on defence and was followed by a similarly themed debate with the title 'Defence in the United Kingdom' on 31 Oct. 2002.

${ }^{37}$ HC Deb 17 Oct. 2002 vol. 390 c528.

${ }^{38}$ HC Deb 21 Oct. 2002 vol. 391 c78W.

39 HC Deb 21 Oct. 2002 vol. 391 c78W.

${ }^{40}$ HC Deb 7 Nov. 2002 vol. 392 c452W.

${ }^{41}$ HC Deb 31 Oct. 2002 vol. 391 c359WH.

${ }^{42}$ HC Deb 23 Oct. 2002 vol. 391 c308W.

${ }^{43}$ E.g. Graham Allen, The Last Prime Minister: Being Honest about the UK Presidency (Thorverton and Charlottesville, 2003), 5.

${ }^{44}$ HC Deb 4 Nov. 2002 vol. 392 c41W.

${ }^{45}$ HC Deb 18 Nov. 2002 vol. 394 c19W, HC Deb 28 Jan. 1991 vol. 184 cc374-5W.

${ }^{46}$ Andrew Blick, How to go to War: A Handbook for Democratic Leaders. With a foreword by Peter Hennessy (2005), 54.

${ }^{47}$ Both these MPs were also invited to give evidence to the select committee on procedure in June 2002 about parliamentary questions. See the house of commons select committee on procedure. Session 2001-2. Minutes of evidence. Ordered by the house of commons to be printed 12 February 2002 (The Stationery Office, 2002), http://www.publications.parliament.uk/pa/cm200102/cmselect/cmproced/622/2021201.htm, 27 Sept. 2013, Q6-9.

${ }^{48}$ HC Deb 27 Nov. 2002 vol. 395 c289W.

${ }^{49}$ HC Deb 7 Jan. 2003 vol. 397 c68W; HC Deb 7 Jan. 2003 vol. 397 cc68-9W.

${ }^{50}$ House of lords select committee on the constitution. Session 2005-06. 15th Report, 8-11. 
${ }^{51}$ Kamal Ahmed, 'Robin Cook is criticised for “unhelpful opinions”, , The Observer, 22 Sept. 2002, 4; Robin Cook’s resignation speech in HC Deb 17 Mar. 2003 vol. 401 cc726-8; Richard NortonTaylor, 'Parliament has “ceded sovereignty”, The Guardian, 16 Jul. 1990, 5.

52 The house of commons liaison committee. Session 2002-3. Minutes of evidence 21 Jan. 2003. Ordered by the house of commons to be printed 21 January 2003. HC 334-i, http://www.parliament.the-stationery-office.co.uk/pa/cm200203/cmselect/cmliaisn/334i/3012101.htm, 27 Sept. 2013, Q127.

53 The house of commons liaison committee. Session 2002-03. Minutes of evidence 21 Jan. 2003, Q125.

54 Tony Wright had referred to the war powers act in a previous question. Factual information about the war powers act was provided by a library research paper Iraq: the debate on policy options, 6975 published on 20 September 2002. The paper outlined the US decision-making process and described the war powers of the US Congress.

55 The house of commons liaison committee. Session 2002-03. Minutes of evidence 21 Jan. 2003, Q126.

${ }^{56}$ Frequent hearings of the prime minister on public policy were first made a convention in 2002.

${ }^{57}$ Simon Hoggart, 'Blair survives pre-conflict recce’, The Guardian, 22 Jan. 2003, 2.

${ }^{58}$ HC Deb 7 Nov. 2002 vol. 392 cc435-441.

59 The division on the amendment ended with the result of 393-199. HC Deb 26 Feb. 2003 vol. 400 cc265-371. The rebellion within the Labour party in the Commons was the largest ever. Philip Cowley, The Rebels: How Blair Mislaid his Majority (2005), 106.

${ }^{60}$ Cowley, Rebels, 107.

${ }^{61}$ House of Commons Library \& Paul Bowers, Parliament and the use of force. House of Commons Library SN/IA/1218, 25 Feb. 2003. 
${ }^{62}$ Bowers, Parliament, 4-11.

${ }^{63}$ HC Deb 27 Feb. 2003 vol. 400 c688W.

${ }^{64}$ Peter Riddell, 'MPs have rights on making love, not war', The Times, 14 Feb. 2003, 16.

${ }^{65}$ HC Deb 18 Mar. 2003 vol. 401 c900.

${ }^{66}$ Teemu Häkkinen, The Royal Prerogative Redefined: Parliamentary Debate on the Role of the British Parliament in Large-scale Military Deployments, 1982-2003. Jyväskylä Studies in Humanities 224 (Jyväskylä, 2014), 264-74.

${ }^{67}$ House of commons public administration committee. Session 2003-4. Fourth report. Taming the prerogative: Strengthening ministerial accountability to parliament. Report, together with formal minutes and appendices. Ordered by the house of commons to be printed 4 March 2004. HC 422 (The Stationery Office, 2004), , 27 Sept 2013, 16-17; The house of lords select committee on the constitution. Session 2005-06. 15th Report, 36, 41-4.

${ }^{68}$ Claire Taylor \& Richard Kelly, Parliamentary Approval for Deploying the Armed Forces: An Introduction to the Issues, House of Commons Library Research Paper 2008/88, 15. See also Nigel D. White, Democracy Goes to War: British Military Deployments under International Law (New York, 2009), 20; for the committee system, see Andrew Tyrie, Mr Blair's Poodle goes to War: The House of Commons, Congress and Iraq (2004), 3-7; The Secretary of State for Justice and Lord Chancellor [Jack Straw], The Governance of Britain, CM 7170, (2007), http://www.officialdocuments.gov.uk/document/cm71/7170/7170.pdf, 28 May 2013, 6-7.

${ }^{69}$ Mark Phythian, 'From Clinton to Bush: New Labour, the USA and the Iraq War', in The British Labour Party and the Wider World, ed. Paul Cothorn and Jonathan Davis (London and New York, 2008), 210-2; John Kampfer, Blair's Wars (2003), 14; Clare Short, An Honourable Deception? New Labour, Iraq and the Misuse of Power (2004), 147.

${ }^{70}$ HC Deb 29 Aug. 2013 vol. 566 part no. 40 cc1425-1556. 